\title{
5
}

\section{Political institutions and economic growth}

Tao Kong

Why have some economies grown and developed, while others have not? Why have some countries experienced rapid economic growth for extended periods, whereas growth in others halted after a relatively short phase? Explaining the erratic and uneven economic growth across countries and over time has been one of the most important and fascinating quests among economists and other social scientists.

Economic theory has indicated a series of determinants likely to affect economic growth significantly. Among these factors, some are immediate variables that explain economic growth in a direct growth accounting fashion, such as physical and human capital accumulation, population growth, technological progress or total factor productivity growth. However, reference to changes in factor endowments and productivity does not explain the ultimate causes of economic growth and development. Rather, it leads to another set of determinants, which fundamentally shape the proximate factors, and often include geographical factors, international integration, and institutions.

While acknowledging that a wide range of factors may significantly affect economic performance, this study focuses on the critical role of institutions in the process of economic growth. Institutions often refer to the quality of formal and informal sociopolitical arrangements (Matthews 1986; North 1990; Greif 1998; Hodgson 1988, 1998; Eggertsson 1990; Acemoglu et al. 2001). Amongst the various institutional variables, political institutions will be brought to the forefront due to the interrelated nature of political and economic decisions and outcomes. Major economic decisions based purely on economic logic are rare. The process of economic growth is always intertwined with political decision-making. 
The main issues considered in this chapter concern the determinants of growth, the importance of institutional factors in shaping alternative feasible growth paths, and their implications. Specifically, it looks into the characteristics of political institutions and the incentive structures relating to various organisational forms, and examines their consequent economic growth effects. Specifically, by distinguishing institutional designs and outcomes, it suggests that governance quality is an important channel through which the growth effects of political institutions operate.

The search for the general pattern of economic performance based on aggregate political institutional characteristics does not necessarily (and presumably should not) suggest a unique economic outcome for a certain political institutional structure, regardless of the socioeconomic environment with which it is associated. This study acknowledges that "economic behaviour is "embedded" in institutions and practices' (Radice 2000:722). Therefore, even if there is a general pattern as to how political institutions affect growth, the optimum implied by the general pattern may differ when applied to different countries.

The focal point of this study is the growth effects of political institutions, but in exploring these effects in reality it is impossible to escape too far from their context. It explores the political institutional characteristics that contributed to the growth path and overall economic performance of China in an international context. In addition, it looks at the implication of the statement that the optimal institutional structure for economic growth varies for countries at different levels of development.

\section{Theoretical analysis}

\section{The literature puzzles}

Economic growth is an immediate outcome of accumulation of various factors and productivity improvement, each of which is a function of underlying incentive structures. As North $(1989,1990)$ and many others have argued, such incentive structures-or, more fundamentally, the institutions that shape such incentive structures-are the deeper determinants of economic growth. Furthermore, since the Second World War a great deal of empirical work based on the varied experiences of myriad developing countries has provided a fairly robust foundation for analysis of the impact of institutional factors (including political institutions) on economic growth. Broadly speaking, there are emerging well-accepted statements on the merits of political institutions that engender a high quality of governance.

The established political science, political economy and economics literatures have acknowledged the important implications of political institutional factors on 
economic growth (Elster 1994; Engerman and Sokoloff 1994; Weingast 1995). The political institutional factors being widely discussed in both theoretical and empirical studies include regime types (Przeworski and Limongi 1993), electoral systems (Persson and Tabellini 2000), and legislative structures (Persson and Tabellini 2000). Many open questions related to the growth effects of political institutions remain, however, such as: what is the overall impact on growth of different political institutions?

Previous studies, which investigated the likely relationship between the patterns of governance and the aggregate characteristics of political institutional arrangements, are mainly theories from political science and political economy. The central theme in the related literature is that political institutional structure entails a trade-off between the credibility of the government's policy commitments and its flexibility of policymaking and implementation (Cox and McCubbins 2000, Maclntyre 2003). However, contingent on the relative risks argued by various researchers, the established literature forcefully pulls in opposite directions.

One school of thought stresses the risk of arbitrary government action and advocates political institutional structures that disperse power, thereby increasing the credibility of government policy commitments (Kydland and Prescott 1977, Clague 1997). A separation-of-power type of regime also tends to reduce the risk of discretionary government behaviour such as expropriation of private properties, thereby positively affecting economic performance (Henisz 2000a, 2000b, Clague 1998, Persson and Tabellini 1990, 2000). The other strand of thought, albeit with diverse reasoning, stresses the importance of flexibility and autonomy in the process of government policymaking and implementation-features often characterised by a centralised-power type of regime. It is argued that, with such political architecture, government is more likely to be able to act swiftly in response to external situations (Haggard 1990; Maclntyre 1994; Woo-Cumming 1999). The division in the literature presents a theoretical puzzle concerning the basic relationship between political institutional structures and their impact on governance quality.

Even more controversially, at the empirical front, existing studies have reached little consensus on whether a particular regime type is associated with a positive or negative overall impact. Or, as much research has concluded, perhaps the link between political institutions and growth, or economic performance in general, is insignificant (Przeworski and Limongi 1993; Benabou 1996; Brunetti 1997). Such inconclusiveness has led to calls for efforts to understand better the impact of political institutions on economic growth. 


\section{Key variables}

Before elaborating the theoretical arguments, the key variables used in this chapter are introduced.

- With respect to the concept of institutions, while there are ideas of all kinds throughout the literature defining various notions of institutions, what they claim and imply often differs. ${ }^{1}$ Following Lin and Nugent (1995), institutions are considered broadly as a set of human-devised constraints that structure human interaction, in part by aiding in forming expectations of what other people will do. Institutions are considered the elements that define the 'rules of the game'. They form the incentive structure of a society, and the political and economic institutions shape economic agents' behaviour. ${ }^{2}$ In consequence, institutions are one of the underlying determinants of economic performance (Coase 1960, North 1989, 1994, 1999).

- Throughout this chapter, the phrases 'economic outcomes', 'economic growth' and the 'level of economic development' are used in precise ways. 'Economic outcomes' is used as the higher order descriptor and 'economic growth' is the indicator or dependent variable selected to study. 'Level of economic development' is used as a static descriptive term and income per capita is used as a proxy for it.

- The structure of political institutions is defined as how governmental decisionmaking powers are shared at the aggregate level among veto players. Such rules are usually granted by constitutions and other key laws (Maclntyre 2003). ${ }^{3}$ This is a relatively generalised approach, which does not apply restrictively to modern western-style democracies, but includes a broader and continuous spectrum of the configuration of aggregate decision-making power among veto players. Political institutional structures shape the capacity and opportunity to exercise discretion over the rules that organise social life.

- Governance quality is a complex notion. It can take many forms and there may be tradeoffs between different dimensions of governance quality. ${ }^{4}$ define governance quality as the capacity of a government to internalise externalities. It particularly concerns the externalities that drive a wedge between the individual and social costs and benefits, where individuals do not fully recognise the positive or negative social effects in the process of individual optimisation. Essentially, the quality of governance is reflected in the capacity of a government to align the interests of self-seeking individuals with that of the society as a whole. In concrete terms, good governance results from government adjustment of incentives through means such as laws, regulatory 
policies, and the provision of other goods and services. With good governance, individual actors' optimising decisions on issues such as investment, education and environment will not deviate too much from the optimal choices for the society.

Importantly, good governance does not necessarily refer to a minimal level of interference by the state in economic affairs. Rather, with good governance, a state seeks to intervene in the economy in ways that internalise the external economic costs of private decisions. Equally important, good governance is not equivalent to good economic performance. If it were, the relationship between good governance and good economic performance would be tautological. Given the current definition, a certain level of governance quality may have very different implications for economic growth depending not only on other determinants of growth, but also the nature or characteristics of the governance itself.

\section{Central arguments}

To answer the question of 'how political institutional configurations affect governance quality' in the light of the diverging literature, this paper builds upon the arguments of political scientist Macintyre (2003) and reconciles the two somewhat contradictory ideas by arguing that political institutional arrangements affect governance quality in a non-monotonic fashion.

Political institutions affect economic growth through the channel of governance quality characterised by two important desirable features, credibility and flexibility. Credibility particularly implies control of predatory and arbitrary government behaviour. Flexibility is about government enjoying a degree of insulation in the decision-making process and being able to respond to various circumstances decisively and in a timely manner. In terms of institutional structure, credibility is often achieved by separation of powers, whilst a relatively concentrated powersharing structure is often endowed with flexibility and decisiveness. As a result, a balanced political institutional configuration is likely to deliver a higher quality of governance than political institutional configurations close to either extreme of the power-sharing spectrum. Because governance quality directly affects the underlying incentive structure of various immediate determinants of economic growth, a balanced political power-sharing structure is also conducive to favourable growth and economic performance in general.

Using economic development levels as a proxy for the different prevailing conditions and challenges of different countries, the present study also highlights the contingent nature of the optimality of political institutions. The differences 
inherent in various countries encompass a host of factors, including history, culture, demographic composition as well as prevailing political systems and socialeconomic conditions. These differences are crucial in determining the feasible set of choices of political institutional arrangements and their subsequent impact on growth. Specifically, depending on the different developmental paths various countries have taken, different arrangements of political institutions to optimise economic performance are often required. Consequently, countries at different levels of economic development may have different optimal structures of political institutions. This implies that a political institutional order that is favourable for economic growth at one time may hinder the sustainability of growth at a later time. In summary, there is no unique optimal political institutional configuration that can fit different countries across development stages. Rather, the compatibility of political orders with the underlying socioeconomic conditions holds the key for sustained economic growth.

\section{Empirical investigation}

I employ quantitative analysis to explore the implications of the theoretical arguments. Data and econometric strategies are introduced before estimation results are discussed.

\section{Political institutional structures}

Most of the institutional-related indicators are proxies for the quality or performance of institutions, rather than the institution itself (Aron 2000). In other words, while these indicators are outcomes instead of attributes of institutions, this important distinction is often not made explicit. In this study, political institutional structures focus on the fundamental configuration of political power, data on which are obtained from the Database of Political Institutions 2000 (Keefer et al. 2002) (hereafter DPI 2000)..$^{5}$ This dataset provides particularly useful information on many aspects of political institutions across 177 countries and over 26 years, 1975-2000. The particular variable used is CHECKS, which provides information on numbers and preferences of veto players in countries' political systems. Higher values of CHECKS indicate higher degrees of checks and balances and lower levels of power concentration.

\section{Governance quality}

Despite a number of measures that have been used in previous studies, institutional quality, as it is typically measured, remains a nebulous concept (Rodrik 2004). ${ }^{6}$ In addition, there has been no consensus on which variable(s) should be used. 
Consequently, different mixes of indicators as well as various weightings of a similar group of variables may have been used to address particular aspects of a research question, not surprisingly leading to conflicting conclusions.

The source of data for governance quality is the governance indicators in Kaufmann et al. (2003), ${ }^{7}$ one of the most comprehensive evaluations of governance quality. Covering 199 countries in 2002, Kaufmann et al. (2003) captures six dimensions, including voice and accountability, political stability, government effectiveness, regulatory quality, rule of law, and control of corruption. The values of these indicators are derived from several hundred variables measuring perceptions of governance drawn from 25 separate data sources constructed by 18 different organisations. ${ }^{8}$ Using an unobserved components model, individual measures of governance perceptions are assigned to the above six categories to capture the key dimensions of governance.

\section{Growth data}

Data on economic growth, initial levels of income per capita and other widely used economic variables such as openness, education attainment, and trade, and so on are obtained from various sources, including the Penn World Table Database 6.1 (Heston and Summers 2002), World Development Indicators (WDI) of the World Bank Data series, Barro and Lee's (1996) international measures of schooling, and so on.

\section{Econometric strategy}

A general observation across countries seems to suggest that countries with relatively more fragmented power-sharing structures (many of which are characterised by modern democratic regimes) arguably exhibit better economic performance than countries with more concentrated structures. It is not at all obvious, however, that fragmented political institutional structures universally lead to more favourable economic performance. It has been emphasised by various researchers, such as Barro (1996), Przeworski and Limongi (1993), and Alesina (1996), that the variance of economic performance of countries with a relatively concentrated power-sharing structure is larger than that of countries with a more fragmented power-sharing structure. ${ }^{9}$ Consequently, if data for all economies are pooled together with a linear specification between political institutional structures and economic performance, regardless of stages of economic development, results are likely to be inconclusive. Relevant to this assertion, Bardhan (2004) examined the multi-dimensional process through which democracy tends to affect the pace and pattern of development. He found that not all of the impact is desirable. ${ }^{10}$ 
Derived from the theoretical arguments, the following hypotheses are tested.

1 Political institutional configuration affects governance quality in a nonmonotonic fashion.

2 Countries at different levels of economic development have different optimal power-sharing structures. The power concentration of the optimal structure decreases, becoming less concentrated with the progress of economic development.

3 Governance quality positively affects economic growth.

4 The impact of political institutional configuration on economic growth is nonmonotonic.

5 The partial effect of institutional configuration on economic growth will depend on the distance between actual structure and optimal structure at the corresponding level of development.

To test the first hypothesis, mean values of CHECKS over the years for every country and the Kaufmann et al. (2003) indicators of governance quality are used. Averaging the values of the relevant variables for a relatively long period of time is a main characteristic shared by many studies, including Scully (1988), Levine and Renelt (1992), Persson and Tabellini (1994), and Helliwell (1994).

One of the methods to examine the existence of a non-monotonic relationship is to test a quadratic specification between the indicators of governance quality and the power concentration index. Henderson (2003) provides some useful econometric strategies, particularly on testing for optimal degree of a variable impact on a dependent variable. The basic model hypothesises that governance quality is a function of political institutional structure and an unobserved variable, included as an intercept.

$\pi_{\mathrm{i}}=\beta_{0}+\beta_{1} C H E C K S+\beta_{2} C H E C K S_{i}^{2}+\varepsilon_{\mathrm{i}}$

where, $C H E C K S_{i}$ denotes the degree of political power dispersal of country $i$, with higher values of $C H E C K S_{i}$ indicating greater fragmentation of power and more checks and balances, $\pi$ denotes levels of governance quality, and $\varepsilon_{i}$ is assumed to be a contemporaneous error term. The working hypothesis for Equation 3.1 is that $\beta_{1}>0$ and $\beta_{0}<0$, and consequently it implies the optimal degree of powersharing is the point $-\beta_{1} / 2 \beta_{2}$, where $\pi$ is maximised.

To test the second hypothesis, the econometric model is similar to Henderson's (2003) approach, in the following form

$\pi_{i}=\beta_{0}+\left(\alpha_{0}+\alpha_{1} \ln \left(\frac{Y_{i}}{N_{i}}\right)\right) C H E C K S_{i}+\beta_{1} \operatorname{CHECKS}_{i}^{2}+\varepsilon_{i}$ 
The working hypothesis is that the collection of terms multiplying powerconcentration is positive, that is, $\left(\alpha_{0}+\alpha_{1} \ln \left(\frac{Y_{i}}{N_{i}}\right)\right)>0$, while $\beta_{1}<0$; and $\alpha_{1}>0$ so that the best structure of political institutions becomes more fragmented as output per worker (or income per capita) increases. The optimal power concentration is given by

$$
-\frac{\alpha_{0}+\alpha_{1} \ln \left(\frac{Y}{N}\right)}{2 \beta_{1}}
$$

An alternative method to test the above hypothesis is to include dummy variables that characterise differences in levels of economic development in the regression. Specifically, countries can be divided into groups according to various income levels. If the estimates of these income dummy variables turn out to have a statistically significant impact on the relationship between governance quality and the configuration of political institutions, it implies various income levels captured by such dummy variables affect the optimal political power concentration levels. Furthermore, with division of the sample countries according to their income groups, the hypothesis is that the benefit of power separation is smaller in lowincome countries than in rich countries. Finally, it is worth noting that this exercise implicitly assumes the actual degrees of power concentration, $z$, are randomly distributed. A normality test based on the Jarque-Bera statistic for skewness and excess kurtosis on CHECKS shows this assumption is not unrealistic with an overall test statistic (chi squared) of 18.56 and $p$-value of 0.0001 .

Hypotheses 3-5 essentially concern growth regressions. Empirical studies on economic growth have nearly reached a consensus on a set of key explanatory variables for growth, including initial level of development, level of investment in physical capital, level of investment in human capital, population growth and openness to world trade. However, enquiries for fundamental determinants of economic growth cry out for a comprehensive growth model that captures various specific considerations. Notably, Bleaney and Nishiyama (2002) investigated a number of influential growth regression specifications, including those of Barro (1997), Easterly and Levine (1997) and Sachs and Warner (1997). They derived a useful encompassing model against which additional explanatory variables can be tested. Specifically, if including untried variables improves the fit of this 'benchmark model', it indicates that additional explanatory power is present or that the new variables have an indirect impact on growth.

The focus of the following growth regression is to explore the core question: does political institutional structure affect growth in a non-monotonic fashion? 
Given the research focus, unlike Bleaney and Nishiyama's (2002) encompassing model where institutional quality (a democracy index) is included as an independent variable, quality of governance is considered an outcome of political institutional structures. In addition, Bleaney and Nishiyama (2002) considered all the regressors effectively independent variables. Consequently, the complex question of endogeneity is not clearly discussed. In the following growth regressions, a twostage least square approach is adopted to help reduce the endogeneity problem. Given that the data on political institutions are independent from economic performance measurements and relate to the quality of governance, DPI can be used as instruments for governance quality measurements in the growth regression.

\section{Results}

Table 5.1 shows that the estimates uniformly rejected a monotonic relationship between political institutional structure and the quality of governance. In the meantime, variation in the results probably reflects the various aspects of governance quality captured by different indicators. For example, the Voice and Accountability indicator captures the degree of transparency. Transparency, as a means to encourage political competition and regulate power, is about the feedback mechanism that rewards good policies and punishes bad ones. In Figure 5.1, fitted values of governance quality (Voice and Accountability) based on the above estimation are demonstrated. In the background, original values of Voice and Accountability are plotted against the proxy of political power structures (CHECKS). The non-monotonic relationship between political institutional structure and governance quality is apparent.

Regression results of estimating Equation 3.2 using six governance quality indicators from Kaufmann et al. (2003) are reported in Table 5.2. In comparison to the results reported in Table 5.1, the econometric model retains a quadratic term to the basic structures of political institutions. In addition, an interaction term of the power-sharing structure (CHECKS) and the log of GDP per capita are included. As expected, the coefficient estimates of CHECKS have positive sign, indicating that the more fragmented the power, the higher the quality of governance. Consistent with the estimates reported in Table 5.1, the set of results in Table 5.2 continues to reject the hypothesis of a monotonic relationship between political institutional structure and governance quality at an overall level.

In particular, the quadratic terms all have opposite signs to the first order terms, despite the finding that, after taking the levels of development into consideration, for some indicators the quadratic term becomes statistically insignificant. The 
Table 5.1 Basic relationship between political institutional structure and governance quality

\begin{tabular}{|c|c|c|c|c|c|c|}
\hline $\begin{array}{l}\text { Dependent } \\
\text { variable } \\
\text { various } \\
\text { governance } \\
\text { quality indicator }\end{array}$ & $\begin{array}{l}\text { Government } \\
\text { effectiveness }\end{array}$ & $\begin{array}{l}\text { Regulatory } \\
\text { quality }\end{array}$ & $\begin{array}{c}\text { Voice and } \\
\text { accountability }\end{array}$ & $\begin{array}{l}\text { Control of } \\
\text { corruption }\end{array}$ & $\begin{array}{l}\text { Rule of } \\
\text { law }\end{array}$ & $\begin{array}{l}\text { Political } \\
\text { stability }\end{array}$ \\
\hline \multicolumn{7}{|l|}{ Structure } \\
\hline CHECKS & $\begin{array}{l}0.87^{* * *} \\
(6.17)\end{array}$ & $\begin{array}{l}0.85^{\star * *} \\
(6.12)\end{array}$ & $\begin{array}{l}1.13^{\star * *} \\
(9.71)\end{array}$ & $\begin{array}{l}0.83^{* * *} \\
(5.68)\end{array}$ & $\begin{array}{l}1.01^{* * *} \\
(7.67)\end{array}$ & $\begin{array}{r}0.78^{* * *} \\
(5.09)\end{array}$ \\
\hline \multicolumn{7}{|c|}{ Structure-squared } \\
\hline$\left(\mathrm{CHECKS}^{2}\right)$ & $\begin{array}{l}-0.07^{\star * *} \\
(-3.70)\end{array}$ & $\begin{array}{l}-0.07^{\star * *} \\
(-3.59)\end{array}$ & $\begin{array}{l}-0.09^{\star * *} \\
(-5.81)\end{array}$ & $\begin{array}{l}-0.07^{* * *} \\
(-3.45)\end{array}$ & $\begin{array}{l}-0.09^{\star * *} \\
(-4.87)\end{array}$ & $\begin{array}{r}-0.08^{* * *} \\
(-3.51)\end{array}$ \\
\hline Constant & $\begin{array}{l}-1.50^{* * *} \\
(-7.64)\end{array}$ & $\begin{array}{l}-1.50^{\text {***}} \\
(-7.74)\end{array}$ & $\begin{array}{l}-2.00^{\star * *} \\
(-12.36)\end{array}$ & $\begin{array}{l}-1.43^{* * *} \\
(-7.02)\end{array}$ & $\begin{array}{l}-1.68^{* * *} \\
(-9.17)\end{array}$ & $\begin{array}{r}-1.26^{* * *} \\
(-5.91)\end{array}$ \\
\hline $\mathrm{N}$ [countries] & 171 & 171 & 171 & 171 & 171 & 168 \\
\hline $\begin{array}{l}\text { Adjusted } \mathrm{R}^{2} \\
\text { Implied optimal } \\
\text { power structure }\end{array}$ & 0.32 & 0.32 & 0.54 & 0.27 & 0.39 & 0.19 \\
\hline$\left(\mathrm{CHECKS}^{*}\right)$ & 6 & 6 & 6 & 6 & 6 & 5 \\
\hline
\end{tabular}

Note: t-ratios are in parentheses. ${ }^{* * *},{ }^{* *},{ }^{*}$ Indicates estimates are significant at 1 per cent level, 5 per cent and 10 per cent levels, respectively.

Source: Author's calculations.

negative signs of structure-squared indicate the positive impact of fragmented power diminishes as the degree of dispersal increases. Whilst the power structure gets less concentrated, the negative effect of fragmentation dominates.

Regardless of the governance indicators employed, the estimate coefficient of the interaction terms (Structure*GDP per capita) is statistically significant and has a positive sign. Corresponding optimal structures of political institutions $\left(C H E C K S^{\star}\right)$ implied by regressions using each of the indicators are calculated. The estimations are generally supportive to the hypothesis that optimal dispersal of political power is positively correlated with income level. Prior research, such as Barro (1997), Helliwell (1994) and Burkhart and Lewis-Beck (1994), has found that the positive relation between income levels and democracy is mostly attributable to the former's impact on the latter rather than the other way around. These results are consistent with the above cited conclusions as well as Lipset's (1959) earlier interpretation of the correlation between income and democracy. 
Figure 5.1 Illustration of the regression results on the relationship between political institutional structure and governance quality

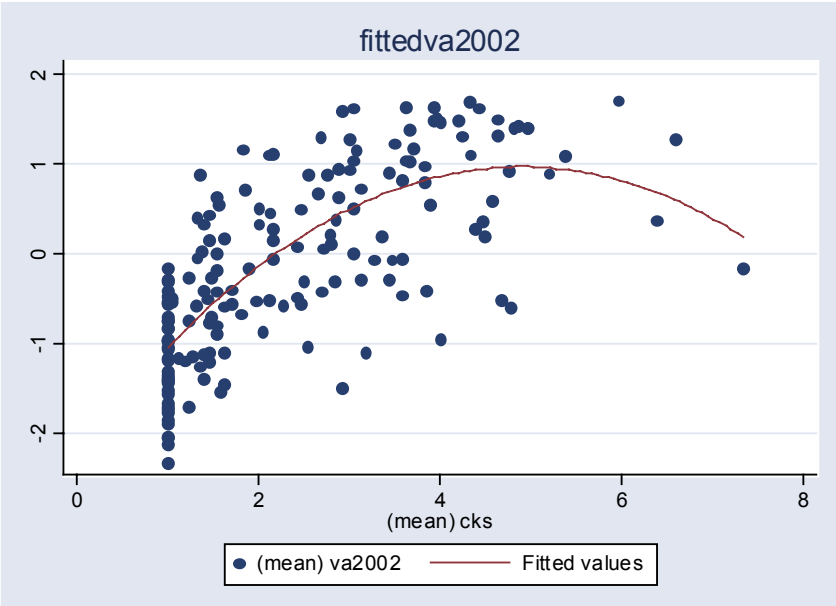

Source: Author's calculations.

Table 5.3 presents the results of a series of growth regressions, including all the key variables identified in Bleaney and Nishiyama (2002). Column (1) shows the specification used as a benchmark in this study, which is built upon the encompassing model of Bleaney and Nishiyama (2002) and extracted institutional quality variables and the squared term of initial income level. ${ }^{11}$ Even though male schooling and terms of trade growth turn out to be statistically insignificant, the overall statistics are satisfactory with adjusted R-squared of 0.80 and pass all diagnostic tests.

Using the results obtained in Column (1) as a basis, the subsequent regressions include additional institutional variables in various specifications. Column (2) shows that the fit improved when predicted values of governance quality are added to the regression. The governance quality indicator presented in Table 5.3 is Control of corruption, ${ }^{12}$ and the predicated values are obtained from estimating Equation 3.2. Indicators of governance quality are treated as outcomes of political institutional structure, and results of this first stage estimation have been reported in Table 5.2. In summary, whilst it passes all the diagnostic tests, the two-stage leastsquare (2SLS) approach improves the adjusted R-squared and reduces the standard deviation of residuals. Thus, the above results provide evidence to support the 


\section{Table 5.2 Estimation results of the relationship between optimal political institutional structure and levels of economic development}

\begin{tabular}{|c|c|c|c|c|c|c|}
\hline $\begin{array}{l}\text { Dependent } \\
\text { variables } \\
\alpha_{0}\end{array}$ & $\begin{array}{c}\text { Control of } \\
\text { corruption } \\
-1.56^{\star * \star} \\
(-5.80)\end{array}$ & $\begin{array}{c}\text { Government } \\
\text { effectiveness } \\
-1.37^{\star \star \star} \\
(-5.26)\end{array}$ & $\begin{array}{l}\text { Rule of law } \\
\qquad \begin{array}{l}-1.31^{* \star *} \\
(-4.96)\end{array}\end{array}$ & $\begin{array}{l}\text { Political } \\
\text { stability } \\
-0.57^{*} \\
(-1.61)\end{array}$ & $\begin{array}{l}\text { Regulatory } \\
\text { quality } \\
-0.76^{\star \star *} \\
(-2.97)\end{array}$ & $\begin{array}{c}\text { Voice and } \\
\text { accountability } \\
0.19 \\
(0.76)\end{array}$ \\
\hline \multicolumn{7}{|l|}{$\begin{array}{l}\alpha_{1} \\
\text { (Coefficient of } \\
\text { CHECKS }\end{array}$} \\
\hline $\begin{array}{l}\text { *InGDP p.c.) } \\
\left(\alpha_{0}+\alpha_{1} \ln \left(\frac{Y_{i}}{N_{i}}\right)\right) \\
\text { (Coefficient of }\end{array}$ & $\begin{array}{c}0.22^{* \star *} \\
(10.35)\end{array}$ & $\begin{array}{l}0.21^{* * *} \\
(9.98)\end{array}$ & $\begin{array}{l}0.20^{* * *} \\
(9.51)\end{array}$ & $\begin{array}{l}0.13^{\star * *} \\
(5.17)\end{array}$ & $\begin{array}{l}0.16^{* * *} \\
(7.85)\end{array}$ & $\begin{array}{l}0.09^{\star * *} \\
(4.32)\end{array}$ \\
\hline & \multicolumn{5}{|c|}{ Structure-squared } & 0.86 \\
\hline$\left(\mathrm{CHECK}^{2}\right)$ & $\begin{array}{c}-0.02^{*} \\
(-1.11)\end{array}$ & $\begin{array}{c}-0.02 \\
(-1.41)\end{array}$ & $\begin{array}{c}-0.02 \\
(-1.35)\end{array}$ & $\begin{array}{l}-0.05^{\star *} \\
(-2.24)\end{array}$ & $\begin{array}{l}-0.05^{\star \star \star} \\
(-2.89)\end{array}$ & $\begin{array}{l}-0.07^{* * *} \\
(-4.54)\end{array}$ \\
\hline $\begin{array}{l}\text { Number of } \\
\text { observations }\end{array}$ & 144 & 144 & 144 & 141 & 144 & 144 \\
\hline $\begin{array}{l}\text { Adjusted } R^{2} \\
\text { Implied optimal } \\
\text { power structur }\end{array}$ & 0.59 & 0.61 & 0.60 & 0.33 & 0.59 & 0.61 \\
\hline$\left(\mathrm{CHECKS}^{*}\right)$ & 5 & 6 & 7 & 5 & 5 & 6 \\
\hline
\end{tabular}

Note: $t$-ratios are in the parentheses.

***, **, * Indicates estimates are significant at 1 per cent level, 5 per cent level and 10 per cent level, respectively.

Source: Author's calculations.

theoretical argument that political institutional structures affect long-run economic growth through the channel of governance quality. Moreover, governance quality has a positive impact on economic growth.

Columns (3) and (4) present the estimation results when political institutional structures (CHECKS) as well as a quadratic specification are included in the growth regression. The null hypothesis is that the relationship between growth and configuration of political institutions (CHECKS) is monotonic. Results show that the inclusion of CHECKS and CHECKS-squared strengthens the results not only by improving the degree of fit and reducing the standard deviation of residuals but also by increasing the significance of the coefficient estimate of the governance quality indicator. Interestingly, in the meantime, the estimate of openness falls from being significant at the 5 per cent level to statistically insignificant. A close 
look at the openness variable given by Sachs and Warner (1997) suggests that openness is defined in such a way that, apart from meeting a series of economic criteria, a country also has to be non-socialist. The inclusion of political institutional structure variables has perhaps picked up some impact of political systems, and therefore weakens the explanatory power of openness.

Column (5) provides the testing results of the hypothesis that long-run growth is negatively affected by distance. The variable distance is the absolute value of the difference between a country's actual political institutional structure (CHECKS) and its optimal structure (CHECKS *) implied by Equation 3.3. The coefficient estimate of distance is negative and statistically significant at the 10 per cent level. These results suggest the data do not reject the hypothesis that such distance is a determinant that helps explain long-run economic growth.

In summary, across the results presented in Columns (3)-(5), the initial state of economic development (log 1965 income per capita), is always statistically significant and negative. Life expectancy (log 1965 life expectancy), ratio of central government saving with respect to GDP (central government saving/GDP), and the ratio of primary products with respect to GDP (primary products/GDP) are significant in all specifications, at least at 5 per cent significance level. The geographical factor, location in tropics (tropical climate), reduces growth, whilst the difference between the growth rates of economically active and total population growth (economically active minus total population growth) increases economic growth. In addition, Columns (4) and (5) present the estimation results when a number of regional dummy variables are included. Similar to Bleaney and Nishiyama's (2002) findings, regional dummies are generally statistically insignificant $(p>0.10)$ except for the East Asian dummy. With respect to the diagnostic tests results, none of the above specifications exhibits significant non-normality of residuals, misspecification or heteroscedasticity. In particular, when the channel of governance quality and the non-monotonic impact of the political institutional structures on growth are considered in Column (4) the adjusted R-squared rises from 0.80 to 0.85 , and the standard deviation of the residuals falls from 0.723 to 0.597 .

\section{Case study of China}

Despite a generally unenthusiastic attitude among economists towards case-study research, case studies have played a broad and versatile role in shaping of economics and political science..$^{13}$ For the purpose of this chapter, the case study mainly focuses on the general economic development of China and the broad direction of changes in the political institutional arrangements. 
China's top leadership includes at least the Politburo and Secretariat of the Chinese Communist Party, the Standing Committee of the State Council, and the top commanders of the military. Within this group, a pre-eminent leader often has the highest decision-making power in the realm of the state, the Party and the military. The precise role of the pre-eminent leader has varied considerably over time, but the core tasks have included personnel appointments at the highest levels, enunciation of ideological principles and-usually after extensive discussion with colleagues-identification of the primary tasks confronting the nation (Riskin 1987). Mao Zedong was the pre-eminent leader until 1976 and, after a brief interregnum, Deng Xiaoping from 1978 till 1990. Even after he officially retired from the political scene in the early 1990s, Deng's direction, development strategy and methods were still continuously implemented in China's reform. Jiang Zemin was designated by Deng as the third pre-eminent leader under Communist Party rule, and assumed leadership, albeit without authority comparable to that of Mao or Deng. Hu Jintao has now moved into the similar posts in the Communist Party (General Secretary), State (President) and military (Chairman of the Central Military Commission). As a result, $\mathrm{Hu}$ Jintao has established himself as the fourth preeminent leader.

In the past 50 years, China has experienced rapid political and economic change. From the establishment of the People's Republic of China to the mid 1970s, China experienced a series of political movements and mass campaigns. Throughout most of this period, the capital-scarce economy followed a Soviet-type economic planning system which essentially promoted a capital-intensive heavy industry development strategy. ${ }^{14}$ Politically, the leadership of Mao tolerated little opposition and concentrated power within the Chinese Communist Party (hereafter CCP) for a considerable length of the period. By the end of the Cultural Revolution in 1976, the Chinese economy faced the formidable task of recovery and reconstruction of a vast nation in ruins. In dramatic contrast, since the late 1970s, the Chinese economy led by Deng has been undergoing a fundamental transition from a planned economy to a market economy and has experienced extraordinary growth for a sustained period.

On the other hand, the Party's control of the nation's political, military and economic power remained unchallenged throughout the period. The major economic transition seems to have been accompanied with a relatively modest change in the aggregate political institutional structure. The conventional wisdom that has emerged from the experiences of various developing countries suggests that successful economic performance often requires a list of pre-requisites to be 


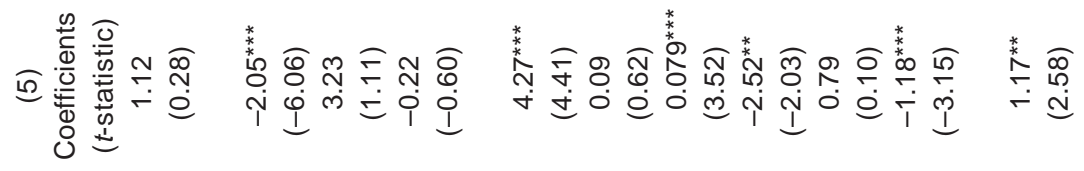

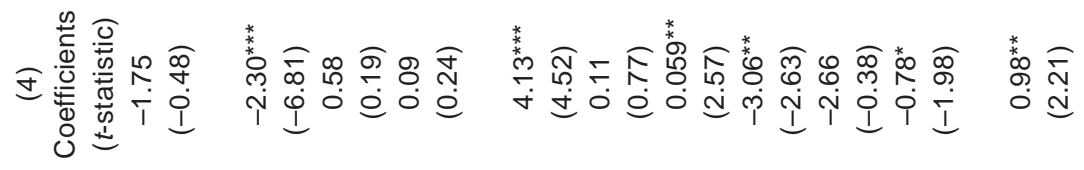

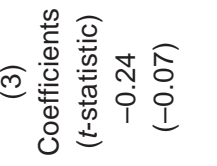

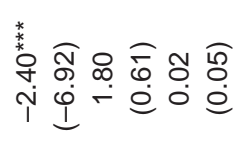

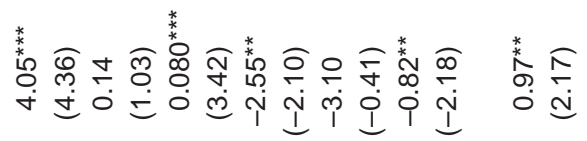

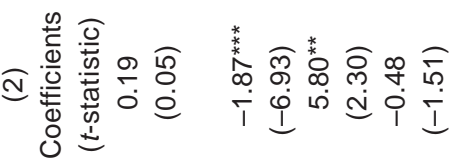

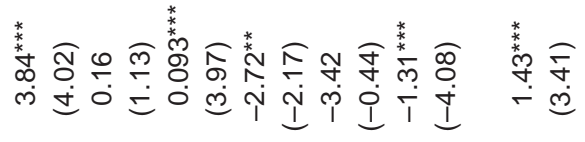

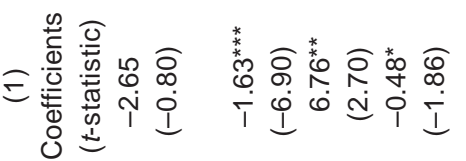

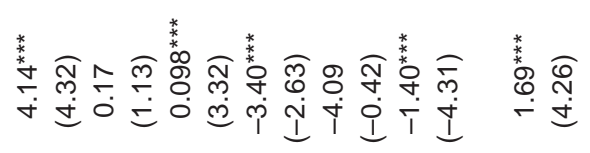
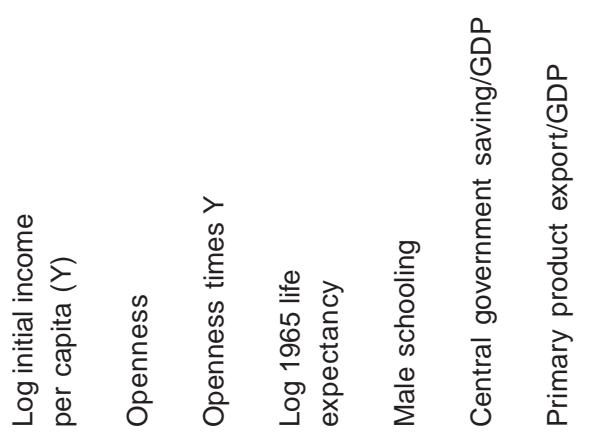
Political institutions and economic growth

悉路

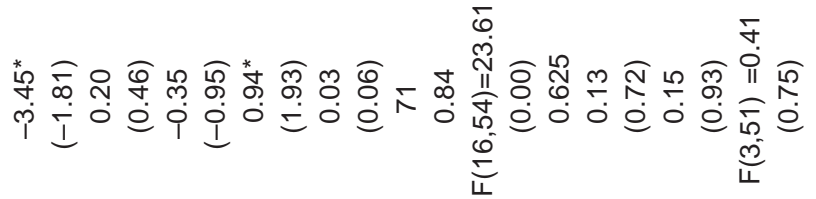

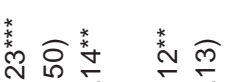

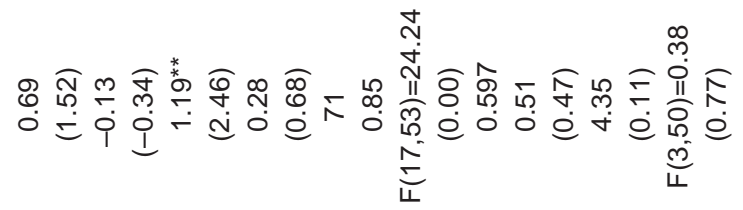

悉

ง ำ

范

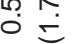

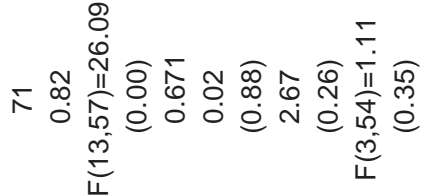

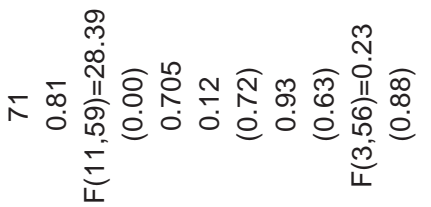

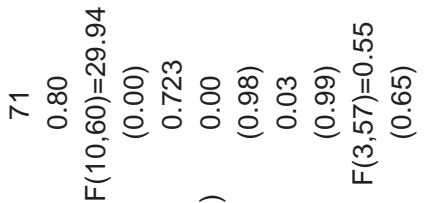

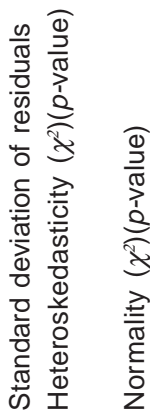

용

\begin{tabular}{l} 
ले \\
D. \\
\hline 0 \\
0 \\
0 \\
0 \\
0
\end{tabular}

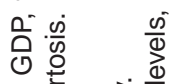
홀 웡ㅎㅇ

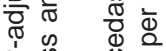
i. 은 낭

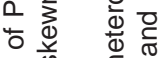
专 के प्ष उ्ٓष 잉

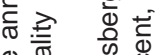

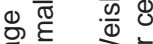

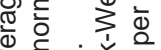
वे

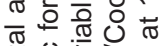

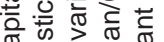
유

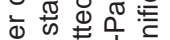
व. os 0 의

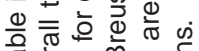

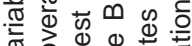
范 등 Ð 은

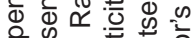
क्ष 0

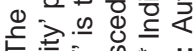

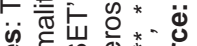
क ह

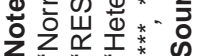


met, which typically include clearly defined and well enforced property rights, effective rule of law, accountable government and so on. Most importantly, it requires restraint on political predation and the uncertainties associated with it. ${ }^{15}$ However, the potential political discretion in China and the absence of a system of private property rights and other conditions for a successful market economy have presented a puzzle and challenged the conventional wisdom in relation to the political basis of economic success.

From a political institutional perspective, the analysis of the impact of political institutions on economic performance postulated in the early sections can assist greatly in understanding the evolution of the political institutional factors and corresponding development path of the Chinese economy.

\section{Political institutional development in the Mao and post-Mao era}

The history of China over the past fifty years can be divided into two periods marked by a political as well as an economic turning point in 1978. The Third Plenum of the Eleventh Party Congress in December 1978 was not only the starting point of new political leadership under Deng Xiaoping, replacing Mao Zedong, but also led to the subsequent reform and economic take-off. A quick glance at Chinese political history may suggest that the political institutional arrangements have not changed a great deal, in the sense that the CCP has always been the only authority over high-level policy since the People's Republic of China was established. However, close examination indicates critical transition has been proceeding throughout the period.

Upon assuming power in 1949, the CCP faced the daunting task of governing a vast nation after a century of foreign invasions, civil warfare, exploitation and natural calamities. In the subsequent several decades, China recorded a series of social campaigns launched by Mao at great cost, including notably the mass campaigns of the Three Antis Campaign, the Five Antis Campaign of the early $1950 s^{16}$, the Great Leap Forward in 1958 and the Cultural Revolution of 1966-76.

After the People's Republic of China was established in 1949, the CCP was led by the People's Central Committee, a group that holds all major civil and military positions. The main decision-making of the Central Committee fell to a smaller Politburo headed by Chairman Mao. In spite of the continuing importance of military power, with cadre advisors attached to military contingents at all levels, the army remained clearly subordinate to the Party. Before the Great Leap Forward of 1958, China followed Mao's strategy of the Soviet model of communist development. During this period, internal to the CCP, the central government was under the 
leadership of Mao and his supporters, with all political and economic decisionmaking power extremely concentrated and unchecked. Externally, criticisms were discouraged and sometimes severely punished. For example, in the mid 1950s, punishment of those who openly criticised the policies, the Party, and, explicitly or implicitly, the leadership under the 'Two Hundred' Scheme clearly demonstrated the intolerance of the political regime in Mao's era. ${ }^{17}$

The Great Leap Forward was initiated with the rationale that an economic miracle of 'super-industrialisation' could be achieved through collectivisation and the use of massive amounts of cheap labour. Contrary to the bold slogan of 'surpassing Great Britain and the United States', the 'great leap' turned into a major economic disaster. Politically, this event also marked the emergence of factional strife within the CCP between bureaucrats led by Deng Xiaoping and Liu Shaoqi and the anti-bureaucrats faction of Mao (Riskin 1987). In the aftermath of the Great Leap Forward, Mao stepped to the sidelines of leadership and Liu and Deng were left in charge of the economic recovery. However, soon after this power shift, Mao regained power and restructured the political architecture so as to eliminate the power base of his rivals and grant his loyalists more power (Shirk 1993). The strife between the two major political factions escalated and became increasingly hostile during the 1960s, the first half of the 1970s and throughout the Cultural Revolution (1966-76)..$^{18}$ The constellation of the top political leadership changed dramatically during the turbulent years, and the violent and intensified factional struggle eventually led to the critical transition of political institutional structures in the late 1970s.

In the wake of the traumatic Cultural Revolution and with the reestablishment of order and stability, it became clear to the leaders of the CCP that to restore prestige and popular trust, it was necessary to demonstrate they could deliver the goods (Shirk 1993). As a result, the members of China's political elite decided to shift the base of party legitimacy from virtue to competence (Shirk 1993). By then, the political struggle was between the dogmatists and anti-dogmatists (Baum 1994). In the second half of 1978, Deng launched an anti-dogmatic campaign under the slogan 'Seek Truth from Facts' as opposed to the dogmatic ideology 'Two Whatevers'. ${ }^{19}$ In a couple of months, the anti-dogmatic faction of Deng gained control over the media, obtained the support of the majority of regional leaders and subsequently established a new era.

Immediately after the anti-dogmatic faction won the battle, the Chinese government set about solidifying political power by implementing new policies, many of which were intended to break the political influence of the dogmatic 
loyalists in the central bureaucracy and to decentralise decision-making power to the more 'loyal' provincial leaders. More fundamentally, Deng's extension of his power base relied on his ability to solve the severe economic problems China faced. Chen Yun's retrenchment strategy suggested the economic problems inherent in the planning and management system would have to be solved through a decentralisation of decision-making (Baum 1994). The political decentralisation has put considerable limits on the central government's discretionary action, which, in turn, provides the beginning of a strong and credible political foundation for market-oriented reform (Montinola et al. 1995).

Importantly, the incentive structures within the government and the Party changed considerably after the first decade of the reform. In the past, central authorities retained a variety of incentives to control the behaviour of lower officials: fiscal control of local government operations allowed them to manipulate local decisionmaking. These incentives have been weakened under the decentralised arrangements. Although the central government retains control over the army and the appointment and dismissal of high-level personnel, the power of these tools is weaker than when they were combined with the more micro-level incentives employed during previous eras. This transformation engendered a significant degree of checks and balances within the central government, while the Party's authoritative position was retained and so was the associated political stability and insulation of the central government. As a result, in comparison to Mao's radicalisation of politics in the 1950s, the aggregate power-sharing structure of the post-Mao era was less concentrated, in spite of the fact that power was reserved within the CCP.

\section{Economic development in the pre-reform and reform periods}

As far as economic development is concerned, from the early 1950s, inspired by the Soviet Union's exceptional economic expansion in the 1930s, Mao applied the 1930s Soviet model to China. Throughout the pre-reform period, the Chinese economy had a Soviet-type planning economic system, which is perhaps best described as an endogenous choice of a comparative-advantage-defying (hereafter CAD) heavy-industry-oriented development strategy (Lin et al. 2003). In accordance with such a development strategy, China's economic structure of China consisted of three integrated components concerning macro-policy, micro-management and a resource allocation mechanism. As Lin et al. (2003) articulated, the macropolicy environment was distorted and characterised by artificially depressed interest rates, over-valued exchange rates and low nominal wages, as well as low prices for living necessities and raw materials. At the micro level, the state-owned enterprises (hereafter SOEs) had no autonomy over management or flexibility in 
the marketplace. In the case of collective agriculture in the countryside,$^{20}$ distorted low prices for agricultural products and a compulsory procurement policy left farmers with neither income that reflected the value of their economic contribution nor any incentive to improve output or productivity. In addition, a centrally-planned administrative system controlled resource allocation. ${ }^{21}$

Under such a development strategy and the resulting economic structure, an overall assessment of the economy during the pre-reform period suggested both allocative and technical inefficiency, as well as appallingly low growth rates. Average annual economic growth rates between 1952 and 1981 were as modest as 0.5 per cent, far below the average growth rates of 19 developing countries in the same period (World Bank 1985). Furthermore, total factor productivity (TFP) growth during the same period was either stagnant or negative depending on the calculation method (Wang and Yao 2001).

Having experienced the major economic setback of Mao's era, the reform leadership concluded that society should be a richer one and that socialism must make considerable use of market forces to provide incentives and signal relative scarcities (Riskin 1987). The economic transition from 1978 began in rural economic management. Replacing collective farming with the Household Responsibility System (hereafter HRS) and revising the compulsory procurement system significantly improved farmers' incentives to enhance productivity and output. Statistical analysis shows that, between 1978 and 1994, the average annual growth of gross agricultural output was 5.1 per cent (Maddison 1998). Furthermore, half of the growth in the agricultural output of 1978-84 could be attributed to growth in productivity, mainly due to the implementation of the HRS (Lin 1992).

Another growth engine in rural China was the non state-owned enterprises, in particular township and village enterprises (TVEs), which flourished from the 1980 s (Garnaut 1996). Operating with hard budget constraint and market mechanisms, non state-owned enterprises are significantly more productive than SOEs in terms of both resource allocation and technical productivity. Specifically, non state-owned enterprises typically operate in labour-intensive industries, which are consistent with the comparative advantage of the Chinese economy. Moreover, operating in a competitive environment, non state-owned enterprises are required to have considerable adaptability for a timely response to price signals. Reflecting its fast expansion, by 1999, the non state-owned enterprise share of gross industrial output had increased to 72 per cent from 24 per cent in 1980 (SSB 1994, 2000).

At the macro-level, the 'open door' symbolises China's sharp turn towards participation in the world market to speed up economic growth and technological modernisation. The reform process involved a massive expansion of the productive 
forces accomplished by means of quasi-capitalist institutions (commodities, markets, corporations, material incentives, 'scientific management', and the like) and the attitudes concomitant to them (Riskin 1987). In the meantime, government was to be divested of its economic management role, enterprises given decisionmaking autonomy, the scope of mandatory planning sharply reduced, that of the market correspondingly increased, and price reform finally undertaken. As China increasingly participated in the international division of labour and took advantage of its comparative advantage, economic reform greatly improved China's economic power and its people's welfare.

\section{Implications}

China has been largely categorised with other highly centralised regimes. Mao was dominant in China during the pre reform period and the political system was formally organised on Marxist-Leninist principles with a socialist or Soviet-type economy. Compared to most other countries, the top leaders wielded enormous power and few if any institutional checks existed to guard against the exercise and abuse of this power (Lieberthal and Oksenberg 1988:4).

With an extremely high degree of central planning, virtually all enterprises were either state-owned or treated as though they were. The central government not only set the priorities, but carried them out administratively by distributing materials and finance to, and ordering output from, the various enterprises (Riskin 1987). However, it was unable to provide the organising principles for a non-bureaucratic socialism that could survive the great prestige of its founder and unite the Chinese people. Instead, it gave rise in the end to a violent and repressive episode in which heady idealism degenerated into warfare between dogmas and factions (Riskin 1987).

From an institutional perspective, the political architecture of the pre-reform period represented Mao's tight grip on political life and policymaking in general. Overly concentrated power often implies lack of checks and balances and carries a major risk of arbitrary and discretionary action. These all contribute to poor governance, which in turn is detrimental to economic development. An unchecked and extremely concentrated political institutional structure explained, at least partly, the catastrophic outcome of the pre-reform period.

In contrast to Mao's era, the political architecture of the reform period has experienced profound change. While the central government and the CCP retained strong leadership at the national level, it has substantially departed from Mao's system, particularly in terms of allocation of power. This is primarily because, 
from the beginning of the post-Mao period, the base of legitimacy of the CCP has fundamentally shifted from political ideology to competence. The means to realise this was by improving economic performance and raising living standards (Shirk 1993). Mao's bias against foreign technology and foreign products had severely hurt China's modernisation. Where Deng Xiaoping differed from his predecessors was in the strength of his desire to turn China into a wealthy and powerful state and his lack of interest in Maoist ideas of a new kind of society where such things as material incentives would play little or no role (Perkins 1994). The shift in the base of legitimacy of the CCP led to a new development strategy characterised by decentralisation of decision-making. In the meantime, this effectively moved the power-sharing structure away from an individual dominating within the Party and introduced a critical degree of checks and balances within the political system.

Moreover, the significant change of the national political architecture during the transition can be viewed in terms of the power of the central government to influence decision-making at the micro-level. In the pre-reform period, state planning and centralisation were stressed and the Party had absolute power and influence. Through bureaucratic and Party channels, the central government was politically capable of implementing village-level programs nationwide (Perkins and Yusuf 1984:4). Such substantial control has fundamentally changed due to the division of authority between central and local governments during the reform. As a result, local governments have primary control over economic matters within their jurisdictions (Montinola et al. 1995). ${ }^{22}$ Specifically, the provincial governments do not serve merely as administrative units of the central government, but have a significant degree of autonomy within their own jurisdiction in terms of economic decisionmaking. This creates limits on the national government's discretionary control.

While this decentralisation of power took place, the central government did not excessively compromise its overall authority. The division of power between national government and subnational government was not operated in an overly fragmented form to the extent that provincial governments behaved like de facto national government in their own jurisdiction. To a large extent, the tendency for excessive fragmentation of power was balanced by the authoritative role of central government over subnational governments within an institutionally durable framework (Montinola et al. 1995; Weingast 1995). For instance, although the most important source of rural economic reform initiatives was perhaps not the central government, as the two major drivers of the growth of rural economy, HRS and TVEs were not central government innovations, the market-oriented reform initiatives were soon embraced and reinforced by the central government on a national scale. The central 
government had the commanding capability to implement reform policies when they were considered appropriate. Similar determination and flexibility to execute the reform initiatives were demonstrated in the SOEs and macro environment reform, from a dual-track price system, ${ }^{23}$ to gradual changes made in interest rate policies, foreign exchange policies and the banking sector.

The relationship between the centre and the provinces was the object of continual reform, as China's leaders sought an appropriate blend of national uniformity and provincial authority (Lieberthal and Oksenberg 1988). Budgetary and other changes enhanced the ability of various provincial and lower level units to make their own decisions. Central-provincial relations were characterised by intense bargaining, with neither capable of totally disregarding the interests and needs of the other (Weingast 1995).

While policies resulted from the initiative of top leaders, they were formulated by the top leaders among contending and powerful bureaucracies with diverse purposes, experience, and resources (Lieberthal and Oksenberg 1988). The Party will rule as trustee of the workers' objective interest in the now distant goal of communism. State enterprises were allowed to keep a share of profits and their managements were permitted more autonomy in production and supply decisions.

In summary, the gradual decline of the personal authority of national leaders and the rise of local governments led to a more balanced political institutional structure in China. The stratified structure of the state promotes a system of negotiations, bargaining, and the seeking of consensus among affected bureaucracies. The policy process in this sphere is disjointed, protracted, and incremental (Lieberthal and Oksenberg 1988). Stronger provincial governments have increasingly modified the political equation, and occupied significant roles in shaping the direction of economic development. ${ }^{24}$

Importantly, the political transition created a more balanced configuration of political institutions, which, in contrast to Mao's regime, do not function within the paradigm of personality-oriented politics. Rather, they retain the authority of central government over the regions whilst institutionalising sufficient autonomy of subnational governments over issues of economic development within their own jurisdictions. At local levels, this led to competition among the provinces, mainly in the form of providing positive incentives to attract investment. At an aggregate level, such competition served as experiments in exploring the most effective ways to achieve faster growth. Thus, without compromising the decisiveness associated with the Party's authoritative role, a natural limit on the misuse of 
power for self interest, favouritism and other discretionary behaviour was created within the authority. As such, a more balanced political institutional structure greatly improved governance quality.

As economic development continues, questions have been raised regarding China's future development. Many observers both within and outside China question the degree to which a one-party system can indefinitely maintain control over an increasingly dynamic and prosperous Chinese society. Will China's current political architecture keep the promise of sustaining rapid economic growth?

It is important to note that the favourable institutional arrangements at a certain period of time do not necessarily translate to arrangements conducive to economic growth all the time. A concentrated power structure may provide the necessary conditions for growth to take place, but the potential perils associated with such a structure can manifest themselves through poor governance, failure to sustain growth or even economic devastation. Garnaut (1999:23) emphasised, 'rapid economic growth is a stressful process... it can destabilise the political order that is responsible for the policies that sustain it, unless the political order itself evolves with the economic structure'. Will the political institutions that have exerted a positive impact on economic performance in the past always be conducive to future economic growth? Economic growth can always end with political convulsion that removes the primacy of the growth objective.

The optimal configuration of political institutions is determined by a wide range of factors, among which the level of development is a crucial one. A failure of political institutions to adjust to the changing conditions and aspirations of the community can undermine social and political cohesion around the objective of growth. This proposition suggests a favourable structure, which has fostered growth for a certain period of time, can gradually become less pertinent due to changes in the broad socio-economic conditions, which can be approximated by levels of development.

The risk of deviation from a balanced structure of political power can eventually constitute an obstacle for future development. This is not to say that a framework that severely concentrates decision-making power does in fact behave in a volatile fashion at any given moment. This will always depend on a complex totality of factors shaping individual decisions that, in an important sense, may not ultimately be knowable. What is emphasised is that the potential for such an outcome was embedded in the political architecture of these countries, and that, as economic and then political pressure mounted, the full potential for policy volatility was laid bare for all to see, with very costly consequences (Maclntyre 2003). 
More generally, perfect policy is not a necessary condition for rapid economic growth. Policies that reduce the gains from trade, market imperfections that keep some resources in relatively unproductive uses, periods of economic instability that inhibit the accumulation of capital, inadequate public investment in education and infrastructure - all hold growth back from attainable levels, and at the same time, depending on their extent, may not be inconsistent with rapid growth. As growth proceeds and the frontiers of world technology and living standards are approached, the tolerance of growth to weaknesses in policy and institutions declines. Poor policy-resulting from professional weakness or political manifestations of resistance to change - can block the continual re-allocation of resources to more productive uses (Garnaut 1993, 1999).

Where Mao kept alive Utopian principles to light the distant goals but failed to consistently chart the way there, his successors focused on the immediate path ahead. In so doing, they have moved into new ideological territory. The earlier reform leadership, Hu Yaobang and Zhao Ziyang, was led by experience to the view that successful economic reform and development would require a widening of the scope for open discussion of policy, for dissent within limits set by the imperatives of continued Communist Party rule, and for reform of the political system to make policy somewhat more open to pressures from a rapidly changing society beyond the central leadership (Garnaut 1999). As economic progress continues, China needs to modify further its political institutional structure so as to be compatible with the evolving status of broad social and economic conditions. Although the seemingly unchanged political structure has in fact undergone critical transition during the reform period, the question is whether such political transition is sufficient to be compatible with China's improved level of development? Economic reform and change had its own momentum that carried along continued social and political change in the local sphere (Garnaut 1999). Having moved quite a few rungs upwards on the economic development ladder, China risks creating institutional impediments to further growth if it does not undertake further institutional reform.

\section{Conclusion}

This chapter argues that a balanced configuration of political power, rather than overly concentrated or excessively fragmented structures, is optimal in terms of maximising economic growth. 
The political institutional arrangements in China can be characterised as a relatively concentrated structure over a period of the past fifty years. The excessively concentrated political institutional structure constituted a major cause of the crisis that ended the Mao era. Since the reform period, however, continuous efforts have been made to alter some aspects of the basic political rules in ways that reshape the national political architecture. As a result, unchallenged authority at the national level gives the government sufficient insulation to make decisive choices, whereas the division of power within the CCP as well as between the various levels of governments provides the political system with a degree of credibility and commitment. With a favourable degree of decisiveness and credibility, the political institutions provided a strong foundation for economic reform and have contributed to the rapid economic growth over the past two and half decades.

The process of economic development is complex and it is imperative to note the fundamental contingency. The influences of political institutions on economic growth are associated with their multifaceted interaction with other institutional and non-institutional variables. An institutional arrangement that has delivered good economic performance at one time may become inappropriate at another time if the level of economic development has significantly changed. As Jones (1988) argued, growth can occur, only within an 'optimality band', where 'factor and commodity markets are freed and the government is neither too grasping nor too weak', but, for growth to be sustained, government has to provide the institutions that were necessary to the effective operation of the market itself: enforcement of the rights to property and contract; freedom of secure movement and exchange over large areas; the personal security that makes long-term investment in education feasible and worthwhile; and much else. ${ }^{25}$ China has so far demonstrated a unique path in transforming from a central-planned economy to an increasingly market-oriented economy. This chapter suggests that the prospect of China's economic future hinges, to a significant degree, on the compatibility of its institutional environment.

\section{Notes}

In general, the definition of institutions is at least twofold. First, an institution is an organised pattern of roles, often enforced with positive and negative sanctions. This strand of the definition is particularly related to firm organisation and governance. Williamson $(1975,1985)$ in particular, has emphasised institutions as a 'governing structure'. As such, the concept of institutions would seem quite compatible with designation of governing structures other than firms (Nelson 
and Sampat 2001). Second, it is considered to be the patterned habits of thought learned by individuals performing those roles.

2 Specifically, well-understood rules establish baseline conditions for human interaction, and give certain predictability as to what other people will do in a particular context (Nelson and Sampat 2001). As such, institutions permit individual decision-making and multi-party negotiation to proceed with some extent of certainty.

3 Veto players refer to those whose consent is necessary for any policy reform and legislative changes (Tsebelis 2000). In this study, political institutional structure, political institutional configuration and political institutional arrangements will be used interchangeably. Fragmentation of power in this study primarily focuses on the horizontal separation of power at the aggregate level rather than vertical decentralisation that disperses state responsibilities to regional branch offices (Oates 1972; Gordon 1983; Sinn 1990). In many previous studies, the term 'separation of power' has often referred to Locke and Montesquieu's concept of the need for separation of the legislative, executive, and judicial branches of government. The main purpose is to avoid usurpation and tyranny by the holder of these powers.

4 For example, World Bank defines governance as the traditions and institutions by which authority in a country is exercised for the common good. This includes (i) the process by which those in authority are selected, monitored and replaced, (ii) the capacity of the government to manage its resources effectively and implement sound policies, and (iii) the respect of citizens and the state for the institutions that govern economic and social interactions (Kaufmann et al. 1999, 2002, 2003).

5 This is the latest version after a series of revision and updates. Earlier versions of DPI include DPI (Beck et al. 2000) and DPI Version 3 (Beck et al. 2001).

6 More specifically, Aron (2000) has pointed out that, in the empirical literature, the terms politics and institutions encompass a wide range of indicators, including institutional quality (often in terms of enforcement of property rights), political instability (riots, coups, civil wars), characteristics of political regimes (election, constitutions, executive power), social capital (the extent of civic activity and organisations), and social characteristics (differences in income and in ethnic, religious, and historical background).

7 Kaufmann, Kraay and Mastruzzi (2003) are an update and expansion of the previous work by Kaufmann, Kraay and Zoido-Lobaton (1999. 2002), for simplicity, therefore, the dataset is referred as KKZ.

8 Details of these 25 sources are listed in Kaufmann et al. $(1999,2002)$ and Kaufmann et al. (2003).

9 For example, Barro writes that 'the theory that determines which kind of dictatorship will prevail is missing' (1996:2). Przeworski and Limongi (1993) cite that economic performance varies 
more dramatically among dictatorships than among democracies, largely because some dictators are constructively 'developmentalist', while others are simply 'thieves'.

10 In particular, Bardhan (2004) pointed out the rewards and punishments by a politician's local constituency need not be consistent with the development goals of the economy as a whole, as in the case of the durable politician who regularly brings the 'pork' home.

11 The inverted U-shape relationship between growth and initial per capita income is not explored in these models because an inclusion of a second-order term of initial income level not only makes the specification unnecessarily more complicated, but also drives down the significance of the first-order term of the initial income level.

12 Using any of the other governance indicators in Kaufmann and Keefer (2003) leads to statistically equivalent results.

${ }^{13}$ For related references to the literature on the methodological issues, see Blaug (1980), and Hausman (1989, 1992).

${ }^{14}$ Lin et al. (2003) include an eloquent analysis on the Chinese economy for the pre-reform period.

15 See North $(1989,1994)$ for the fundamental role of institutions, particularly property rights.

16 The Three Antis Campaign was against corruption, waste, and excessive bureaucracy. The Five Antis Campaign was against bribery, tax evasion, theft of state property, cheating on government contracts, and stealing economic information.

17 The 'Two Hundred' Scheme was the campaign to 'Let a hundred flowers bloom and let a hundred schools of thought contend'. At the beginning of the campaign, it was encouraged by Mao for mainly intellectuals to speak out freely. But as critics flushed into the society, Mao abruptly shifted gears and denounced the criticisms as 'poisonous weeds'. Many of those who had criticised openly were struck with demotions, prison sentences and other forms of punishment.

${ }^{18}$ See Chan (1985) and Meisner (1986) for detailed accounts of the Cultural Revolution.

19 The 'Two Whatevers' refers to the statement that 'we must resolutely uphold whatever policy decisions Chairman Mao made, and must unswervingly follow whatever instructions Chairman Mao gave'. This statement was contained in a joint editorial, entitled 'Study the Documents Well and Grasp the Key Link' of 7 February 1977 in the People's Daily, Hongqi Journal and Liberation Army Daily.

20 Mao and his supporters introduced the Mass Line approach, and the subsequent formation of the agricultural cooperatives began in 1955. In the following year, cooperatives became farming collectives and soon accounted for more than 90 per cent of the peasant population.

${ }^{21}$ Lin et al. (2003) provide a persuasive analysis of the economic rationale behind the joint presence of these three components in light of the CAD strategy.

22 Montinola et al. (1995) summarised that the political institutional structure of China, which they term as 'market preserving federalism', encompasses a set of conditions that governs the 
allocation of authorities and responsibility among different levels of government. In the case of China, its political institutional structure shares, to some degree, each of the important features of market-preserving federalism. Such an assertion is primarily based on the balance of power between the central government and local provincial governments.

${ }_{23}$ A dual-track price system was introduced in 1984. It allowed the SOEs to sell their output in excess of quotas at market prices and plan their production accordingly.

${ }^{24}$ Examples of provincial governments as an influential part of economic policy decision-making include the endorsement of market-oriented reform, open-door policy and opposing the reversal of decentralisation.

\section{References}

Acemoglu, D., Johnson, S. and Robinson, J.A. 2001. 'Colonial origins of comparative development: an emprical investigation', American Economic Review, 91(5):1369-1401.

Alesina, A., Ozler, S., Roubini, N. and Swagel, P., 1996. 'Political instability and economic growth', Journal of Economic Growth, 1(2):189-213.

Aron, J., 2000. 'Growth and institutions: a review of the evidence', World Bank Research Observer, 15(1):99-135.

Bardhan, P., 1999. Democracy and Development: a complex relationship, in I. Shapiro and C. Hacker-Cordon (eds), Democracy's Value, Cambridge University Press, Cambridge.

Barro, R. 1996. 'Democracy and growth', Journal of Economic Growth, 1(1):1-28. __ and Lee, J., 1996. 'International measures of schooling years and schooling quality', American Economic Review, 86(2):218-23.

— 1997. Determinants of Economic Growth: a cross-country empirical study. MIT Press, Massachusetts.

Baum, R., 1994. Burying Mao: Chinese politics in the age of Deng Xiaoping, Princeton University Press, Princeton.

Beck, T., Clarke, G., Groff, A., Keefer, P. and Walsh, P., 2001. 'New tools and new tests in comparative political economy: the database of political institutions', World Bank Economic Review, 15(1):165-76.

Benabou, R., 1996. 'Inequality and growth', NBER Macroeconomics Annual, MIT Press, Cambridge:11-76.

Bleaney, M. and Nishiyama, A., 2002. 'Explaining growth: a contest between models', Journal of Economic Growth, 7(1):43-56.

Brunetti, A., 1997. Politics and Economic Growth: a cross-country data perspective, Development Centre of the Organisation for Economic Cooperation and 
Development, Paris.

Burkhart, R.E., and Lewis-Beck, M.S., 1994. 'Comparative democracy: the economic development thesis', American Political Science Review, 88(4):90310.

Chan, A., 1985. Children of Mao: personality development and political activism in the red guard generation. University of Washington Press, Seattle.

Clague, C. (ed.), 1997. Institutions and Economic Development: growth and governance in less-developed and post-socialist countries, Johns Hopkins University Press, Baltimore.

__, 1998. 'Economics, institutions, and economic development', in E.M.U. Karol Soltan and V. Haufler (eds), Institutions and Social Order, University of Michigan Press, Michigan:201-29.

Coase, R., 1960. 'The problem of social cost', Journal of Law and Economics, 3:1-31.

Cox, G.W. and McCubbins, M., 2000. 'The institutional determinants of economic policy outcomes', in S. Haggard and M.D. McCubbins (eds), Presidents, Parliaments, and Policy, Cambridge University Press, New York.

Easterly, W., and R. Levine. 1997. 'Africa's growth tragedy: policies and ethnic divisions', Quarterly Journal of Economics, 112(4):1203-50.

Eggertsson, T., 1990. Economic Behaviour and Institutions, Cambridge University Press, Massachusetts.

Elster, J. 1995. 'The impact of constitutions on economic performance', Proceedings of the World Bank Annual Conference on Development Economics 1994, World Bank, Washington, DC:209-226.

Engerman, L. and Sokoloff, K.L., 1994. Factor endowments: institutions and differential paths of growth among new world economies: a view from economic historians of the United States, NBER Working Paper No. H0066, National Bureau of Economic Research, Massachusetts.

Garnaut, R., 1993. 'The market and the state in economic development: some questions from East Asia and Australia', in M.A.B. Siddique (ed.), A Decade of Shann Memorial Lectures 1981-90 and the Australian Economy, Academic Press International, Nedlands:303-23.

—, Kuo, S. and Ma, G. (eds), 1996. The Third Revolution in the Chinese Countryside, Cambridge University Press, New York.

_ 1999. 'Twenty years of economic reform and structural change in the Chinese economy', in R. Garnaut and L. Song (eds), China: twenty years of reform, Asia Pacific Press, Canberra:1-26. 
Gordon, R.. 1983. 'An optimal tax approach to fiscal federalism', Quarterly Journal of Economics, 98(4):567-86.

Greif, A. 1998. 'Historical and comparative institutional analysis', American Economic Review, 88(2):80-84.

Haggard, S., 1990. Pathways from the Periphery: The politics of growth in the newly industralizing countries, Cornell University Press, Ithaca.

Helliwell, J. 1994. 'Empirical linkages between democracy and economic growth', British Journal of Political Science, 24(2):225-48.

Henderson, V., 2003. 'The urbanization process and economic growth: the sowhat question', Journal of Economic Growth, 8(1):47-71.

Henisz, W.J., 2000a. 'The institutional environment for economic growth', Economics and Politics, 12(1):1-31.

_ 2000b. 'The institutional environment for multinational investment', Journal of Law, Economics and Organization, 16(2):334-64.

Heston, A. and Summers, R., 2002. Penn World Table Version 6.1, Center for International Comparisons at the University of Pennsylvania, Pennsylvania. Available online at http://pwt.econ.upenn.edu/.

Hodgson, G., 1988. Economics and Institutions. Polity Press, Cambridge.

—, 1998. 'The approach of institutional economics', Journal of Economic Literature, 36(1):166-92.

Jones, E.L. 1988. Growth Recurring:economic change in world history, Clarendon Press, New York.

Kaufmann, D., Kraay, A. and Zoido-Lobaton, P., 1999. Governance matters, World Bank, Washington, DC (unpublished).

_ - 2002. Governance matters II: updated indicators for 2000/01, World Bank, Washington, DC (unpublished).

Kaufmann, D. and Kraay, A., Governance Matters III: governance indicators for 1996-2002 and 2003, World Bank, Washington, DC (unpublished).

Keefer, P., 2002. Database of political institutions: changes and variable definitions, Development Research Group, World Bank, Washington, DC.

Kydland, F.E., and Prescott, E.C., 1977. 'Rules rather than discretion: the inconsistency of optimal plans', Journal of Political Economy, 85(3):473-91.

Levine, R. and Renelt, D., 1992. 'A sensitivity analysis of cross-country growth regression, American Economic Review, 82(4):942-63.

Lieberthal, K., and Oksenberg, M., 1988. Policy Making in China Leaders, Structures, and Processes, Princeton University Press, Princeton.

Lin, J.Y., 1992.'Rural reforms and agricultural growth in China', American Economic Review, 82(1):34-51. 
—_ and Nugent, J.B., 1995. 'Institutions and economic development', in J. Behrman and T.N. Srinivasan (eds), Handbook of Development Economics, Volume 3A, North Holland, Amsterdam:2301-70.

— Cai, F. and Li, Z., 2003. The China Miracle: development strategy and economic reform, The Chinese University Press, Hong Kong.

Lipset, S.M., 1959. 'Some social requisites of democracy: economic development and political legitimacy', American Political Science Review, 53(1):69-105.

Maclntyre, A. (ed.), 1994. Business and Government in Industralising Asia, Cornell University Press, Ithaca.

_ P.J. Katzenstein (ed.), Cornell Studies in Political Economy. Cornell University Press, Ithaca.

Maddison, A., 1998. Chinese Economic Performance in the Long Run, Organization for Economic Cooperation and Development (OECD), Paris.

Matthews, R.C.O., 1986. 'The economics of institutions and the sources of growth', Economic Journal, 96(384):903-18.

Meisner, M.J., 1986. Mao's China and After: a history of the People's Republic, Free Press, Collier Macmillan, New York.

Montinola, G., Qian, Y. and Weingast, B.R., 1995. 'Federalism, Chinese style: the political basis for economic success', World Politics, 48(1):50-81.

Nelson, R.R. and Sampat, B.N., 2001. 'Making sense of institutions as a factor shaping economic performance', Journal of Economic Behavior and Organization, 44:31-54.

North, D.C., 1989. 'Institutions and economic growth: an historical introduction', World Development, 17(9):1319-32.

_- 1990. Institutions, Institutional Change, and Economic Performance, Cambridge University Press, Massachusetts.

— 1994 . 'Economic performance through time', American Economic Review, 84(3):359-68.

_ 1999. Understanding the Process of Economic Change, Institute of Economic Affairs, London.

Oates, W.E., 1972. Fiscal Federalism, Harcourt Brace Jovanovich, New York. Perkins, D.H. and Yusuf, S., 1984. Rural Development in China, John Hopkins Press, Baltimore.

Perkins, D.H., 1994. 'Completing China's move to the market', Journal of Economic Perspectives, 8(2):23-46.

Persson, T. and Tabellini, G., 1990. Macroeconomic Policy, Credibility and Politics, Harwood Academic Publishers, Chru. 
_ 1994 . 'Does centralization increase the size of government?', European Economic Review, 38(3-4):765-73.

_ (eds), 2000. Political Economics: explaining economic policy, Zeuthen Lecture Book Series, MIT Press, London.

Przeworski, A. and Limongi, F., 1993. 'Political regimes and economic growth', Journal of Economic Perspectives, 7(3):51-69.

Radice, H., 2000. 'Globalization and national capitalisms: theoreizing convergence and differentiation', Review of International Political Economy, 7(4):719-42.

Riskin, C., 1987. China's Political Economy: the quest for development since 1949, Oxford University Press, Oxford.

Rodrik, D., 2004. 'Getting institutions right', CESifo DICE, Report 2:10-15.

Sachs, J.D. and Warner, A., 1997. 'Fundamental sources of long-run growth', American Economic Review, Papers and Proceedings, 87(2):184-88.

Scully, G.W., 1988. 'The institutional framework and economic development', Journal of Political Economy, 96(3):652-62.

Shirk, S., 1993. The Political Logic of Economic Reform in China, University of California Press, Berkeley.

Sinn, H., 1990. Taxation and the birth of foreign subsidiaries, NBER Working Paper 3519, National Bureau of Economic Research, Massachusetts.

State Statistics Bureau (SSB), various years. China Statistical Yearbook, China Statistics Press, Beijing.

Tsebelis, G., 2000. 'Veto players and institutional analysis', Governance, 13(4):44174.

Wang, Y. and Yao, Y., 2001.'Sources of China's economic growth, 1952-99:incorporating human capital accumulation', China Economic Review, 14(1):32-52.

Weingast, B.R., 1995. 'The economic role of political institutions: market-preserving federalism and economic development', Journal of Law, Economics and Organization, 11:1-31.

Williamson, O.E., 1975. Markets and Hierarchies, Analysis and Anti-Trust Implications: a study in the economics of international organization, Free Press, New York.

—, 1985. The Economic Institutions of Capitalism, Free Press, New York.

Woo-Cummings, M. (ed.), 1999. The Developmental State, Cornell University Press, Ithaca.

World Bank. 1985. China, Economic Structure in International Perspective, World Bank, Washington, DC.

_ 